\title{
Assessment of Potential Oil and Gas Resources in Source Rocks of the Alaska North Slope, 2012
}

The U.S. Geological Survey estimated potential, technically recoverable oil and gas resources for source rocks of the Alaska North Slope. Estimates (95-percent to 5-percent probability) range from zero to 2 billion barrels of oil and from zero to nearly 80 trillion cubic feet of gas.

\section{Introduction}

The U.S. Geological Survey (USGS) in 2012 completed an assessment of undiscovered, technically recoverable oil and gas resources in three source rocks of the Alaska North Slope. Although these source rocks are known to have generated oil and gas that migrated into conventional accumulations, including the super-giant Prudhoe Bay field, no attempt has been made to produce oil or gas directly from the source rocks. Thus, they represent an unexplored frontier for shale-oil and shale-gas resources.

\section{Geology of Alaska North Slope Source Rocks}

Three source rocks were assessed: (1) The Triassic Shublik Formation, (2) the lower part of the Jurassic-Lower Cretaceous Kingak Shale, and (3) the Cretaceous pebble shale unit and Hue Shale, together called Brookian shale in this fact sheet. The Shublik Formation mostly contains a mixture of Type I and IIS kerogen, and oil in conventional accumulations sourced from the Shublik is

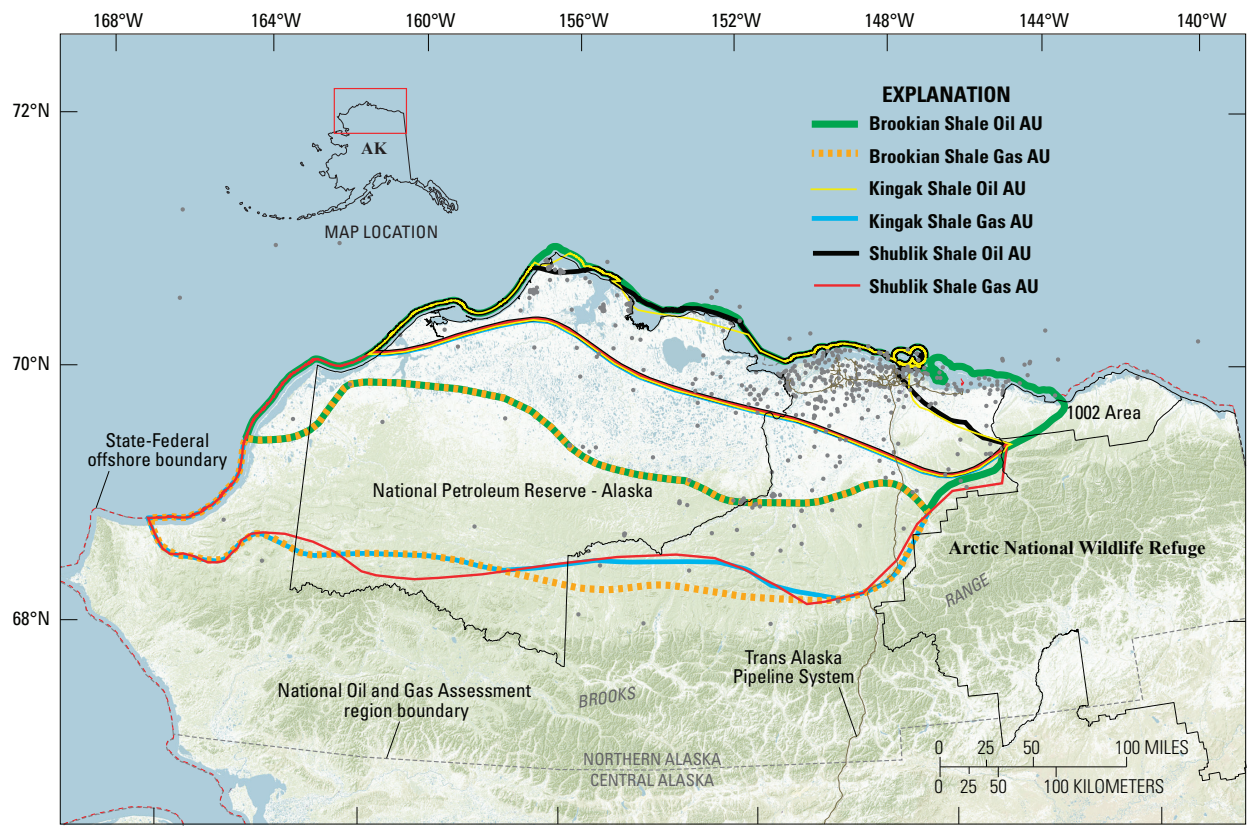

Figure 1. Northern Alaska province showing boundaries of assessment units (AU) discussed in text. Assessment units extend offshore to State-Federal boundary except where strata are absent because of erosion or nondeposition. Small gray dots are exploration wells drilled in search of conventional petroleum accumulations. of relatively low gravity $\left(23-39^{\circ} \mathrm{API}\right)$ and high sulfur (more than 1.5 percent). In contrast, the Kingak and Brookian shales mostly contain a mixture of Type II and III kerogen, and oil in conventional accumulations sourced from those rocks is of relatively high gravity ( $\left.35-42^{\circ} \mathrm{API}\right)$ and low sulfur (less than 0.3 percent). These source rocks occur at depths that range from less than 3,000 feet along the northern coast to more than 20,000 feet in the Brooks Range foothills. Over this range of depth, thermal maturity of the source rocks grades from the onset of oil generation in the north, through the oil window, and well into the dry gas window in the south. Vitrinite reflectance data plus the results of time-temperature and petroleum-generation modeling were used to estimate a boundary between oil (north) and gas (south) assessment units for each source rock. Southern boundaries of the gas assessment units were based on either the surface expression of the northern limit of tectonic structures formed during the Early Cretaceous or the modeled location of the 4 percent vitrinite reflectance contour, whichever is farther north.

Considering that no attempt has been made to produce oil or gas from the source rocks (limited oil production and gas tests from the Shublik are considered local occurrences of adequate reservoir quality in conventional accumulations), the presence of brittle reservoir lithologies is an important consideration. Both the Shublik and Brookian source rocks include rock types that are brittle and in which natural fractures are common. Brittle lithologies include limestone, phosphatic limestone, and chert in the Shublik and very fine grained sandstone, siltstone, concretionary carbonate, and silicified tuff in the Brookian. In contrast, the Kingak is mostly clay shale that deforms plastically, and brittle lithologies generally are absent.

Additional geological information was used to define assessment units and to evaluate the potential for oil and gas to occur in the source rocks. Maps of gamma-ray response in geophysical logs from exploration wells, regional distribution of overpressure, and reconstructed history of burial, uplift, and cooling of North Slope source rocks were among the most important considerations.

Shale-oil and shale-gas formations in the lower 48 States were used as geologic and engineering analogs in the assessment. Analog data include "estimated ultimate recovery" (EUR) from shale-oil and shale-gas wells, mean drainage areas of wells (cell sizes), and ranges of well success ratios. Key assessment input data are listed in table 1. 


\section{Resource Summary}

USGS estimates of potential, technically recoverable shale-oil resources in northern Alaska (95- to 5-percent probability) range from zero to 2 billion barrels of oil (table 2). Oil resources are about equally distributed between the Shublik and Brookian source rocks, with significantly less potential in the Kingak (table 2).

Estimates of potential, technically recoverable shale-gas resources in northern Alaska range from zero to nearly 80 trillion cubic feet of gas (table 2). Gas resources are heavily concentrated in Shublik source rocks, with significantly less gas potential in the Brookian and small gas potential in the Kingak (table 2). These estimates include "nonassociated" gas in the Shublik and Brookian shale-gas assessment units, as well as "associated" gas in all three shale-oil assessment units.

Estimates of technically recoverable natural gas liquids (NGL), from both nonassociated and associated gas, range from zero to more than 500 million barrels (table 2). The Shublik is estimated to contain most of the NGL.

Although mean resource values are included in table 2, they must be considered within the context of the large range of uncertainty associated with estimation of undiscovered, continuous resources in source rocks from which no attempt has been made to produce either oil or gas. Therefore, mean values are not emphasized in this fact sheet.

\section{For Further Information}

Supporting reports on geology and methodology used in the Alaska North Slope assessment are in progress. Assessment results and related reports are available at the USGS Energy Web site:

http://energy.usgs.gov

\section{North Slope Source-Rock Resource Assessment Team}

David W. Houseknecht (dhouse@usgs.gov), William A. Rouse, Christopher P. Garrity, Katherine J. Whidden, Julie A. Dumoulin, Christopher J. Schenk, Ronald R. Charpentier, Troy A. Cook, Stephanie B. Gaswirth, Mark A. Kirschbaum, and Richard M. Pollastro.

\section{Acknowledgments}

We thank Mike Whalen (University of Alaska-Fairbanks), the Alaska Department of Natural Resources (Paul Decker, Robert Swenson, and Marwan Wartes), and participants in a public workshop held in Anchorage in October 2011 for input regarding the geology of petroleum source rocks of Arctic Alaska prior to the USGS assessment.

Table 1. Key assessment input data for shale-oil and shale-gas assessment units of the Alaska North Slope.

[EUR (estimated ultimate recovery per well), cell size, and success ratios are based on U.S. lower-48 shale-oil and shale-gas analogs. MMBO, million barrels of oil; BCFG, billion cubic feet of gas; AU, assessment unit; \%, percent, Min., minimum; Max., maximum. For the average EUR variables, the mode columns contain the medians of the EUR distributions.]

\begin{tabular}{|c|c|c|c|c|c|c|c|c|c|c|c|c|c|c|c|c|c|c|c|c|}
\hline \multirow{2}{*}{ Assessment input data } & \multicolumn{4}{|c|}{ Shublik Shale Oil AU } & \multicolumn{4}{|c|}{ Shublik Shale Gas AU } & \multicolumn{4}{|c|}{ Brookian Shale Oil AU } & \multicolumn{4}{|c|}{ Brookian Shale Gas AU } & \multicolumn{4}{|c|}{ Kingak Shale Oil AU } \\
\hline & Min. & Mode & Max. & Mean & Min. & Mode & Max. & Mean & Min. & Mode & Max. & Mean & Min. & Mode & Max. & Mean & Min. & Mode & Max. & Mean \\
\hline Potential production area (million acres) & 5.0 & 7.3 & 7.5 & 6.6 & 20.0 & 25.6 & 30.0 & 25.2 & 14.0 & 18.2 & 20.0 & 17.4 & 14.0 & 17.3 & 20.0 & 17.1 & 5.0 & 7.4 & 8.0 & 6.8 \\
\hline Average drainage area of wells (acres) & 100 & 160 & 400 & 220 & 75 & 150 & 200 & 142 & 100 & 200 & 400 & 233 & 120 & 150 & 180 & 150 & 100 & 160 & 400 & 220 \\
\hline Percentage of AU in sweet spots (\%) & 0.5 & 15.0 & 40.0 & 18.5 & 2.0 & 20.0 & 50.0 & 24.0 & 0.2 & 10.0 & 40.0 & 16.8 & 0.5 & 5.0 & 10.0 & 5.2 & 0.0 & 0.0 & 10.0 & 3.3 \\
\hline \multicolumn{21}{|l|}{ Input for inside sweet spots } \\
\hline Average EUR (MMB0, oil; BCFG, gas) & 0.020 & 0.050 & 0.250 & 0.061 & 0.200 & 0.800 & 2.500 & 0.887 & 0.010 & 0.040 & 0.100 & 0.043 & 0.040 & 0.400 & 1.000 & 0.426 & 0.010 & 0.040 & 0.100 & 0.043 \\
\hline Success ratio $(\%)$ & 70 & 85 & 95 & 83 & 50 & 80 & 95 & 75 & 50 & 70 & 95 & 72 & 40 & 65 & 95 & 67 & 50 & 70 & 95 & 72 \\
\hline \multicolumn{21}{|l|}{ Input for outside sweet spots } \\
\hline Average EUR (MMBO, oil; BCFG, gas) & 0.010 & 0.025 & 0.125 & 0.031 & 0.100 & 0.400 & 1.250 & 0.444 & 0.005 & 0.010 & 0.060 & 0.013 & 0.040 & 0.200 & 0.500 & 0.214 & 0.005 & 0.010 & 0.060 & 0.013 \\
\hline Success ratio (\%) & 0 & 10 & 70 & 27 & 1 & 10 & 50 & 20 & 0 & 10 & 30 & 13 & 0 & 0 & 10 & 3 & 0 & 5 & 25 & 10 \\
\hline
\end{tabular}

Table 2. Alaska North Slope shale-oil and shale-gas assessment results.

[MMBO, million barrels of oil; BCFG, billion cubic feet of gas; MMBNGL, million barrels of natural gas liquids. Results shown are fully risked estimates. For gas accumulations, all liquids are included as NGL (natural gas liquids). Undiscovered gas resources are the sum of nonassociated and associated gas. F95 represents a 95-percent chance of at least the amount tabulated; other fractiles are defined similarly. Fractiles are additive under the assumption of perfect positive correlation. AU, assessment unit. AU probability is the chance of at least one well within the AU having a production capacity of the minimum estimated ultimate recovery. TPS, total petroleum system. Gray shading indicates not applicable.]

\begin{tabular}{|c|c|c|c|c|c|c|c|c|c|c|c|c|c|c|}
\hline \multirow{3}{*}{$\begin{array}{l}\text { Total petroleum systems (TPS) } \\
\text { and assessment units (AU) }\end{array}$} & \multirow{3}{*}{$\underset{\text { probability }}{\mathrm{AU}}$} & \multirow{3}{*}{$\begin{array}{l}\text { Field } \\
\text { type }\end{array}$} & \multicolumn{12}{|c|}{ Total undiscovered resources } \\
\hline & & & \multicolumn{4}{|c|}{ Oil (MMBO) } & \multicolumn{4}{|c|}{ Gas (BCFG) } & \multicolumn{4}{|c|}{ NGL (MMBNGL) } \\
\hline & & & F95 & F50 & F5 & Mean & F95 & F50 & F5 & Mean & F95 & F50 & F5 & Mean \\
\hline \multicolumn{15}{|l|}{ Shublik TPS } \\
\hline Shublik Shale Oil AU & 0.95 & Oil & 0 & 428 & 928 & 463 & 0 & 418 & 981 & 462 & 0 & 10 & 26 & 12 \\
\hline Shublik Shale Gas AU & 0.95 & Gas & & & & & 0 & 36,612 & 72,195 & 38,405 & 0 & 184 & 442 & 205 \\
\hline \multicolumn{15}{|l|}{ Brookian TPS } \\
\hline Brookian Shale Oil AU & 0.90 & Oil & 0 & 421 & 955 & 449 & 0 & 818 & 1,996 & 898 & 0 & 20 & 51 & 22 \\
\hline Brookian Shale Gas AU & 0.90 & Gas & & & & & 0 & 2,124 & 4,375 & 2,184 & 0 & 21 & 46 & 22 \\
\hline \multicolumn{15}{|l|}{ Kingak TPS } \\
\hline Kingak Shale Oil AU & 0.40 & Oil & 0 & 0 & 117 & 28 & 0 & 0 & 238 & 57 & 0 & 0 & 6 & 1 \\
\hline Kingak Shale Gas AU & & Gas & \multicolumn{12}{|c|}{ Not quantitatively assessed } \\
\hline Total continuous resources & & & 0 & 849 & 2,000 & 940 & 0 & 39,972 & 79,785 & 42,006 & 0 & 235 & 571 & 262 \\
\hline
\end{tabular}

